【論文】

\title{
レーザフラッシュ法による積層試料の 熱拡散率解析法の開発 \\ Development of the Analysis Method of the Thermal Diffusivity of Multi-layered Sample by Laser Flash Method
}

\author{
細野和也* 西剛史** 太田弘道** \\ Kazuya Hosono, Tsuyoshi Nishi, and Hiromichi Ohta
}

\begin{abstract}
高温域を含む積層試料の熱拡散率測定を目的として, 試料表裏面から放射損失がある条件で試料温 度式をラプラス空間で導き，得られた解を用いて積層試料の熱拡散率をラプラス空間で最小二乗法に て決定する方法を検討した，具体的には，熱拡散率と放射損失を表すビオ数を独立変数として解析す る方法（直接法）とまず実空間における試料裏面温度低下の減衰時定数を求めて，この值を用いて両 者を導出する方法（時定数法）を取り上げ，両方法とも解析対象層の熱拡散率を求められることを精 度評価により実証した。また直接法の場合，短い測定時間で熱拡散率解析が可能であることを確認し た.
\end{abstract}

In order to measure the thermal diffusivity of multi-layered material by a laser flash method, analyzing method of the thermal diffusivity of any layer was investigated using the multi-layered sample temperature equation obtained in the Laplace space under the radiation loss. First method is a search of a root-mean-square deviation minimum in the Laplace space under the condition that the thermal diffusivity and the Biot number are independent variable (Direct method). Second method is a method to search the minimum under the condition that the theoretical cooling time constant equals to the cooling time constant of the measured temperature data of real space (Cooling time constant method). It was confirmed that it is possible to determine the thermal diffusivity and Biot number by both methods and the thermal diffusivity can be analyzed by Direct method using data in short measurement time.

[Keywords: flash method,multilayer material,thermal conducitivity,thermal diffusivity,biot number]

\section{1.はじめに}

工業材料の熱伝導率測定に高精度, 簡便性, 短時間測定 等の利点があるレーザフラッシュ法が多く使用される.こ の手法では, 均質, 緻密, 不透明な単層材料の他に基材表 面に遮熱コーティングを施した 2 層材や, 断熱材等によく 見られるポーラスな材料の表裏面に不透明な膜材を貼り 付けた 3 層材の研究が多くなされている[1-7].これらの多 くは, 2 層材あるいは 3 層材の特定層の熱拡散率を試料表 裹面からの放射損失が無視できる室温付近での測定を対 象としている。しかし実際には，放射損失が無視でき

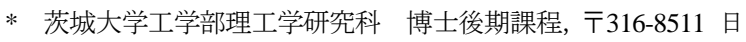
立市中成沢町 4-12-1. Graduate School, Department of Material Engineering, Ibaraki University, Hitachi 316-8511

FAX: 0836-51-7165 E-mail:hosono@jutem.co.jp

** 茨城大学工学部マテリアル工学科, テ316-8511 日立市中成 沢町 4-12-1.

Dept. of Materials Engineering, Ibaraki University, 4-12-1 Nakanarusawa-cho, Ibaraki, 316-8511.
ない高温域での測定の必要性も高い.

Baba[1]，Akoshima ら[2]は積層試料の熱拡散率を実時 間の試料温度応答を用いて解析する面積熱拡散時間法を 開発した.また，これらの手法を用い熱放射の影響も考慮 した解析法は，2010 年 JISH8453「遮熱コーティングの熱 伝導率測定方法」の附属書として, また 2016 年 2 月に ISO18555 として制定されている，熱放射を考慮したこれ らの面積熱拡散時間法は放射損失がない場合の多層材理 論式の解を, 従来の単層の熱放射を考慮した理論解に基づ く補正法[8-9]と同様の方法で補正している.この方法は各 層の熱物性值が大きく異なることがない場合は正しいが， 各層の物性值が大きく異なる場合には単層の場合と温度 分布が変わってくるため誤差が生じることが䀣念される. 本論文では高温での測定で問題となる試料表裹面からの 放射損失を考慮したラプラス空間における解析法を取り 上げ, 試料理論温度式の導出とその温度式を用いたレーザ フラッシュ法による積層試料の熱拡散率の精度について 
検証した.

\section{2. 試料温度式および解析法}

本項では, 放射損失がある場合の積層試料裏面の温度式 をラプラス空間で導き,この結果を用いて積層試料の熱拡 散率解析方法を示寸.

\section{1 試料温度式}

定常温度 $T_{0}$ から加熱光照射に伴う温度変化を $T$ とし, 試料表裏面から放射損失がある場合の積層試料裏面温度 式を導く．この際，各層間には熱抵抗が無いものとする. 層の数を $n$, 加熱光が照射される側を表面 $x=0$ ，各層を添 え字 $i$, 層の厚さを $d l$, 各層の右端の $x$ 座標を $L$, 試料全 体の厚さを $L_{n}$, 試料に吸収されたレーザ光の熱流束を $Q f(t)$, 試料表裏面からの放射損失を表わ寸無次元のビオ数をそ れぞれ $B_{i 0}, B_{i 1}$ とする.

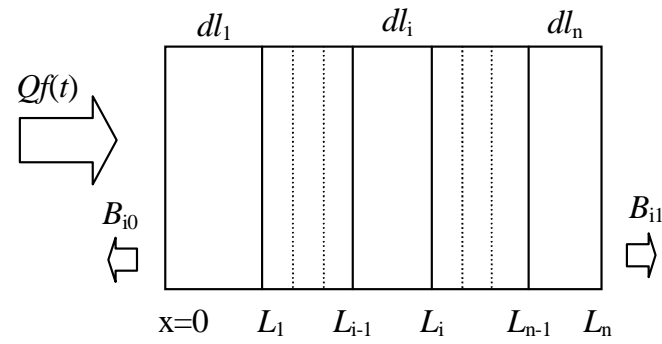

Fig. 1 Thermal conduction model

各層の温度の微分方程式, 初期条件, 境界条件式を $\mathrm{Eq}(2.1)$

$\sim \mathrm{Eq}(2.12)$ に示す.

第 1 層

$$
\begin{aligned}
& \frac{\partial T_{1}}{\partial t}=\alpha_{1} \frac{\partial^{2} T_{1}}{\partial x^{2}} \\
& T_{1}(x, 0)=0 \\
& \frac{\partial T_{1}(0, t)}{\partial x}=-\frac{Q f(t)}{k_{1}}+\frac{B_{i 0}}{L_{n}} T_{1}(0, t) \\
& T_{1}\left(L_{1}, t\right)=T_{2}\left(L_{1}, t\right) \\
& k_{1} \frac{\partial T_{1}\left(L_{1}, t\right)}{\partial x}=k_{2} \frac{\partial T_{2}\left(L_{1}, t\right)}{\partial x}
\end{aligned}
$$

第 $\mathrm{i}$ 層

$$
\begin{aligned}
& \frac{\partial T_{i}(x, t)}{\partial t}=\alpha_{i} \frac{\partial^{2} T_{i}(x, t)}{\partial x^{2}} \\
& T_{i}(x, 0)=0 \\
& T_{i}\left(L_{i}, t\right)=T_{i+1}\left(L_{i}, t\right) \\
& k_{i} \frac{\partial T_{i}\left(L_{i}, t\right)}{\partial x}=k_{i+1} \frac{\partial T_{i+1}\left(L_{i}, t\right)}{\partial x}
\end{aligned}
$$

第 $\mathrm{n}$ 層

$\frac{\partial T_{n}(x, t)}{\partial t}=\alpha_{n} \frac{\partial^{2} T_{n}(x, t)}{\partial x^{2}}$

$T_{n}(x, 0)=0$

$\frac{\partial T_{n}\left(L_{n}, t\right)}{\partial x}=-\frac{B_{i 1}}{L_{n}} T_{n}\left(L_{n}, t\right)$

ここで $t$ は時間， $\alpha$ は熱拡散率， $k$ は熱伝導率である. 試 料に吸収される単位面積当たりのエネルギーを $Q$, 熱流束 を $Q f(t)$ とする. これらの式をラプラス変換・解析して試 料裏面温度式 $\mathrm{Eq}(2.13)$ を得る. ラプラス変換した試料温度 は上部に横バーを付寸。

$$
\bar{T}_{n}\left(L_{n}, p\right)=\frac{Q f(p) 2 r_{n}}{\left[\begin{array}{l}
\left(\left(r_{1}+B_{i 0} / L_{n}\right)\left(r_{n}-B_{i 1} / L_{n}\right) \exp \left(-r_{n} L_{n}\right) S_{21}\right. \\
+\left(\left(r_{1}+B_{i 0} / L_{n}\right)\left(r_{n}+B_{i 1} / L_{n}\right) \exp \left(r_{n} L_{n}\right) S_{22}\right. \\
-\left(\left(r_{1}-B_{i 0} / L_{n}\right)\left(r_{n}-B_{i 1} / L_{n}\right) \exp \left(-r_{n} L_{n}\right) S_{11}\right. \\
-\left(\left(r_{1}-B_{i 0} / L_{n}\right)\left(r_{n}+B_{i 1} / L_{n}\right) \exp \left(r_{n} L_{n}\right) S_{12}\right.
\end{array}\right]}
$$

試料裏面温度式の各変数は, Eq.(2.14)〜 Eq.(2.20)により与 えられる。

$$
\begin{aligned}
& \left\{\begin{array}{ll}
S_{11} & S_{12} \\
S_{21} & S_{22}
\end{array}\right\}=\prod_{i=1}^{n-1} G_{i i+1}=G_{12} G_{23} \ldots G_{n-1 n} \\
& G_{i i+1}=\left\{\begin{array}{ll}
\left(G_{i i+1}\right)_{11} & \left(G_{i i+1}\right)_{12} \\
\left(G_{i i+1}\right)_{21} & \left(G_{i i+1}\right)_{22}
\end{array}\right\} \\
& \left(G_{i i+1}\right)_{11}=\left(1+\frac{k_{i+1} r_{i+1}}{k_{i} r_{i}}\right) \frac{\exp \left(-r_{i} L_{i}+r_{i+1} L_{i}\right)}{2}
\end{aligned}
$$


$\left(G_{i+1}\right)_{12}=\left(1-\frac{k_{i+1} r_{i+1}}{k_{i} r_{i}}\right) \frac{\exp \left(-r_{i} L_{i}-r_{i+1} L_{i}\right)}{2}$

$\left(G_{i+1}\right)_{21}=\left(1-\frac{k_{i+1} r_{i+1}}{k_{i} r_{i}}\right) \frac{\exp \left(+r_{i} L_{i}+r_{i+1} L_{i}\right)}{2}$

$$
\left(G_{i+1}\right)_{22}=\left(1+\frac{k_{i+1} r_{i+1}}{k_{i} r_{i}}\right) \frac{\exp \left(+r_{i} L_{i}-r_{i+1} L_{i}\right)}{2}
$$

ここに $r_{i}$ はラプラス変数 $p$ と $i$ 層熱拡散率 $\alpha_{i}$ を用いて Eq.(2.20)で表される.

$$
r_{i}=\sqrt{\frac{p}{\alpha_{i}}}
$$

なお同式において加熱光を $\delta$ 関数, ビオ数を 0 とした式 は放射損失が無い場合の馬場らによって求められている ラプラス空間の試料裏面温度式[1]と一致することを 2〜5 層材で確認した.

\section{2 解析法}

本研究では, 解析対象以外の層については, 従来法と同 様に熱拡散率, 密度, 比熱容量, 厚さを既知とし, 解析対 象層については密度, 厚さ以外のこれらの值(熱拡散率と 比熱容量) と放射損失の大きさを表すビオ数を未知として 熱拡散率を導出する方法を検討した. これらの值のうちビ 才数は副次的に得られる值であるが得られた值を精度検 証のために示した. また実際に温度応答曲線の解析を行う 場合には解析対象の層の物性值が導出される值に影響を 与えることが予想される.この点を考慮して解析対象の層 の比熱容量と得られる熱拡散率の值の関係についても検 討を行った. 比熱容量については熱拡散率との同時解析に より精度の良い值が得られるかどうかについても検討を 行った.

解析はラプラス空間で行う 2 つ方法により行った. 具 体的には, 一つは対象層の熱拡散率, 比熱容量, 放射損失 を表すビオ数を求めるものとし, これらを独立変数として 解析する方法 (直接法とする)，もう一つは実空間におけ る試料裏面温度の低下領域の減衰時定数を求め, この值を 既知として, ラプラス空間で熱拡散率, 比熱容量を求める 方法 (時定数法とする) である. 最小二乗法によりこれら の值を導出した. 2 乗偏差 $R$ は解析対象の熱拡散率, 比熱 容量とビオ数の関数であり, 次式で与えられる.

$$
R\left(\alpha_{i}, C_{i}, B_{i}\right)=\sum_{j}\left[Q T_{n}\left(L_{n}, p_{j}\right)-E_{j}\right]^{2}
$$

ここに $E_{j}$ は測定データをラプラス変換したものであり, ラプラス変数は次式により設定する.

$$
\begin{aligned}
& p_{j}=\frac{p t_{\text {min }}+\left(p t_{\text {max }}-p t_{\text {min }}\right) \times j /\left(n_{p}-1\right)}{t_{m}} \\
& j=0 \sim n_{p}-1
\end{aligned}
$$

$p t_{\min }\left(=p_{\min } \times t_{\mathrm{m}}\right.$ at $\left.\mathrm{j}=0\right)$ と $p t_{\max }\left(=p_{\max } \times t_{\mathrm{m}}\right.$ at $\left.j=n_{\mathrm{p}}-1\right)$ はラプラ 不変数 $p$ と測定時間 $t_{\mathrm{m}}$ の積の最小值と最大值であり, そ の間に $n_{\mathrm{p}}$ 個のラプラス変数を設定する. この際, 試料表 裏面は同じ黒化処理して測定することが多いので, そのビ 才数は等しいものとして共通ビオ数 $B_{i}$ と定義した.

2 乗偏差 $R$ を用いて $\partial R / \partial Q=0$ とすることにより, Eq.(2.23)のレーザ光の単位面積当たりの試料に吸収され た熱量 $Q$ が得られる.

$$
Q=\sum E_{j} \bar{T}_{j} / \sum \bar{T}_{j}{ }^{2}
$$

$Q$ を Eq.(2.21)に代入することにより $Q$ を含まない 2 乗偏 差式が得られ, 以下に示寸直接法および時定数法解析に使 用することができる.

\section{(1) 直接法}

直接法による解析の場合, 解析対象層の熱拡散率, 比熱 容量, ビオ数を独立変数としてこれらを逐次設定して 2 乗偏差がより小さくなる組み合わせを探索し, 2 乗偏差の 最小值を与える变数の組み合わせが求める熱物性值とな る. 具体的には, 比熱容量およびビオ数の初期值を複数設 定し,これらの各組み合わせに対して 2 乗偏差を最小とす る熱拡散率をニュートン法で求めると同時にその 2 乗偏 差值を求め, この 2 乗偏差值がより小さくなるよう比熱容 量とビオ数を複数再設定することを繰り返して解析対象 層の熱拡散率, 比熱容量, ビオ数を求める方法である. 本 方法は熱放射損失に伴う温度低下の減衰時定数を実空間 で求める必要が無いので測定時間の制限が無くなり, 裏面 温度の立ち上がり部分のみのデータでも原理的に解析可 能である. 装置の長時間側における安定性が低かったり試 料の熱拡散率が小さかったりする場合などで試料裏面温 度の低下領域の安定が得られない場合に適した方法であ る.

\section{（2）時定数法}

時定数法の場合, 理論式 $\mathrm{Eq}(2.13)$ より得られる理論時定 数 $\tau_{\mathrm{th}}$ と実空間試料裏面温度測定データの低下領域から 得られる時定数 $\tau_{\mathrm{m}}$ を等しく寸る付加条件のもとに 2 乗偏 差最小值を探索し, 解析対象層の物性值を求める方法であ 
る.レーザ照射後の試料裏面温度が低下寸る領域では熱放 射の寄与が支配的となるため, この領域のみを使って熱放 射の大きさを見積もると精度が向上する. ラプラス空間に おいて熱放射の影響を見積もる場合, ラプラス変換はレー ザ照射直後のデータの重みが大きいためレーザ照射後の 非常に長時間側まで解析しないと熱放射の影響が支配的 にならない.一方実際の測定ではあまりに長時間の測定は レーザフラッシュ法の利点である断熱性や迅速性が損な われるため避けられる傾向がある.このため, ラプラス空 間の試料裏面温度式より実空間の温度低下の減衰時定数 を求め, この值を実空間の温度低下の減衰時定数と比較し て放射の影響を見積もり, 比熱容量と熱拡散率については ラプラス空間における最小二乗法で求める手法が時定数 法である.

本方法の場合, 理論時定数式が必要であり, 以下で導く. 試料表面を極短時間加熱した後,十分時間経過した後には 加熱波形がどのようなものであれ試料全体がほぼ等温で 低下寸るので, 裏面温度は時定数 $\tau$ に従って低下 $\left(T_{n}\left(L_{n}, t\right)\right.$ $\propto \exp (-t / \tau))$ 寸る.この時間領域におけるラプラス空間に おける試料裏面温度は Eq.(2.24)で近似される。

$$
\bar{T}_{n}\left(L_{n}, p\right) \propto \frac{1}{[p+1 / \tau]}
$$

ラプラス空間においては, 時間が経過することはラプラス 変数 $p$ を小さくすることに対応する. 試料裏面温度式 Eq.(2.13)をラプラス変数で展開し, 式(2.24)との対応から 理論時定数が得られる. 2 層材の場合の時定数を以下に示 す.

$$
\tau=\frac{\left[\begin{array}{l}
2\left(\frac{k_{1} d l_{1}}{\alpha_{1}}+\frac{k_{2} d l_{2}}{\alpha_{2}}\right) \\
+\frac{B_{i}}{L_{2}}\left\{\left(\frac{d l_{1}^{2}}{\alpha_{1}}+\frac{d l_{2}{ }^{2}}{\alpha_{2}}\right)\left(k_{1}+k_{2}\right)+2 d l_{1} d l_{2}\left(\frac{k_{1}}{\alpha_{1}}+\frac{k_{2}}{\alpha_{2}}\right)\right\} \\
+\frac{B_{i}^{2}}{L_{2}{ }^{2}}\left\{d l_{1} d l_{2}\left(\frac{k_{1} d l_{1}}{\alpha_{1}}+\frac{k_{2} d l_{2}}{\alpha_{2}}\right)+\frac{k_{1} k_{2}}{3}\left(\frac{d l_{1}^{3}}{\alpha_{1} k_{1}}+\frac{d l_{2}{ }^{3}}{\alpha_{2} k_{2}}\right)\right\}
\end{array}\right]}{2\left[\frac{B_{i}\left(k_{1}+k_{2}\right)}{L_{2}}+\frac{B_{i}{ }^{2} k_{1} k_{2}}{L_{2}{ }^{2}}\left(\frac{d l_{1}}{k_{1}}+\frac{d l_{2}}{k_{2}}\right)\right]}
$$

層数がより多い場合も同様の手順で時定数を求めること が可能である.

任意層数の場合も Eq.(2.25)同様の時定数式が得られる
が, 分子をビオ数 0 次項, 分母をビオ数が 1 次の項までで 近似すると任意層数に対して時定数近似式 $\tau_{\text {app }}$ として次 式を得る.

$$
\tau_{\text {app }}=L_{n} \sum_{i=1}^{n} \frac{k_{i} d l_{i}}{\alpha_{i}} /\left[B_{i}\left(k_{1}+k_{n}\right)\right]
$$

この近似の精度を確認するために単層の場合について Eq.(2.25)および Eq.(2.26)に対応する式を求め比較する. 同 式において $\alpha_{1}=\alpha_{2}, k_{1}=k_{2}, d l_{1}+d l_{2}=L$ とすることにより単 層の場合の時定数式 Eq.(2.27), Eq.(2.28)を得る.

$$
\tau=L^{2}\left(1+B_{i}+B_{i}{ }^{2} / 3 !\right) /\left[\alpha\left(2 B_{i}+B_{i}{ }^{2}\right)\right]
$$

$$
\tau_{\text {app }}=L^{2} /\left[2 B_{i} \alpha\right]
$$

近似時定数 $\tau_{\text {app }}$ の精度を Eq.(2.29)より求め図 2 に示す. これよりビオ数が 0.02 程度より小さい時, 近似時定数式 の精度は $1 \%$ より高いことが確認される. 試料裏面から外 部に放出される熱流束が $\varepsilon \sigma T^{4}$ に等しいものとすると, 概 略 Eq.(2.30)が成立する場合にこの時定数近似式が適用可 能と考えられる.ここで $\varepsilon$ は放射率， $\sigma$ はステファンボル ツマン定数である。

$$
\frac{\tau_{\text {app }}-\tau}{\tau}=-\frac{B_{i}+B_{i}^{2} / 3}{2\left(1+B_{i}+B_{i}^{2} / 3 !\right)}
$$

$$
0.02>\frac{4 \varepsilon \sigma L_{n} T_{0}^{3}}{k_{n}}
$$

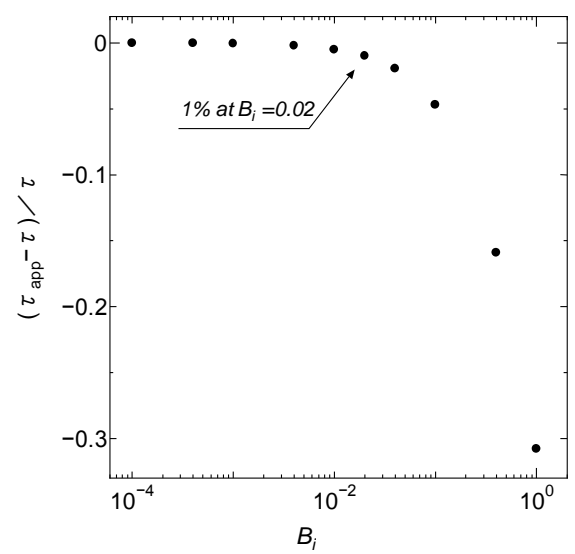

Fig. 2 The accuracy of approximate cooling time constant $\tau_{\text {app }}$ 


\section{3 試料裏面温度データ}

積層試料の解析方法検証のため,ここではひとつのモデ ルケースとして多層材のすべての層の物性值が等しい場 合について検討を行った. 具体的には図 3 に示寸単層試料 の裏面温度データを時間空間裏面温度式[10]を用いて作 成し，これを同一物性值を有する積層試料の裹面温度デー タと考えて計算および解析を行った. 裏面温度データの最 後のデータの時間（測定時間 $\left.t_{\mathrm{m}}\right)$ は, 特性時間 $\left(t_{0}=L^{2} /\right.$ $\left.\pi^{2} / \alpha ; 6 \mathrm{~ms}\right)$ の 20 倍 $\left(t_{\mathrm{m}}=20 \times t_{0}\right)$ であり, サンプリング 周期 $t_{\mathrm{s}}$ は $10 \mu \mathrm{s}$ である. Eq.(2.3)のレーザから試料に吸収さ

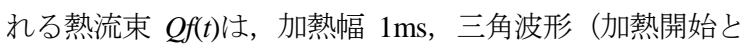
同時に所定の值で加熱開始し, その後, 直線的に加熱が減 少し加熱幅時間後に加熱が 0 となる）とした.

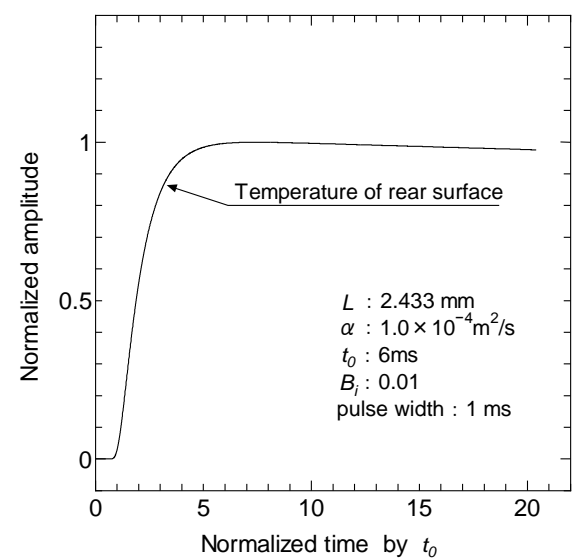

Fig. 3 Temperature response curve of rear surface calculated by [10]

\section{4 ラプラス変数の設定}

ラプラス空間における熱拡散率解析においては, 使用す る測定データ記録条件と理論式導出条件が一致すること が理想である.しかし, 現実にはいくつかの誤差要因が存 在する. そのひとつは測定データの有限性である. ラプラ ス変換は無限時間における積分が含まれるため, 有限時間 の裏面温度データと無限時間応答に対する理論式を用い た比較が避けられない. 図 3 の場合, 測定時間は特性時間 の 20 倍のデータであるが, 解析に使用する試料裏面温度 理論式は測定時間無限大に対応している.しかしこの問題 はラプラス変数を大きな值とすることによって影響を抑 えることができる.これより熱拡散率解析精度が高くなる ラプラス変数の下限はデータ有限性により, また上限は時 刻原点でのデータが取れないこと, 加熱光を $\delta$ 関数近似す る場合に生じる時刻原点のずれ等により規定される.この ため, 以下のような検討を行いラプラス変数の設定条件を
検討した. 具体的には Eq.(2.31)の条件のもとに Eq.(2.22) によりラプラス変数を設定し, 解析に用いる規格化時間 $n_{\mathrm{t}}$ (特性時間 $t_{0}$ を単位とした測定時間 $\left(n_{\mathrm{t}} \times t_{0}\right)$ までの裹面 温度データ）とラプラス変数の関係を求めた. この際, ラ プラス変数の適正值をより詳細に明らかにするために $p t_{\max }$ と $p t_{\min }$ の差を次式に示すように 0.1 と小さい值とした.

$$
p t_{\max }=p t_{\min }+0.1
$$

結果を図 4 に示す.解析に用いる規格化時間が長ければ ラプラス変数の設定許容範囲が広いが, 短い規格化時間の 場合には許容範囲が狭くなる. 例えば試料厚さ $0.993 \mathrm{~mm}$ の場合, 解析に用いる規格化時間 $n_{\mathrm{t}}=20$ の時 $10.1 \leq p t_{\min } \leq$ 114.8, 規格化時間 $n_{\mathrm{t}}=3$ の時 $14.0 \leq p t_{\min } \leq 16.7$, 規格化時間 $n_{\mathrm{t}}=2$ の時 $p t_{\mathrm{min}}=16.0$ で熱拡散率解析精度が $1 \%$ となる. 試 料厚さが厚いほど熱拡散率解析精度が $1 \%$ となる $p t_{\min }$ の 範囲は上限, 下限とも広くなる傾向があり, 試料厚さ 3.441 $\mathrm{mm}$ の場合, 解析に用いる規格化時間 $n_{\mathrm{t}}=20$ の時 $9.6 \leq p t_{\min }$ $\leq 315.9, n_{\mathrm{t}}=1.5$ の時 $14.3 \leq p t_{\min } \leq 21.8$ となる.

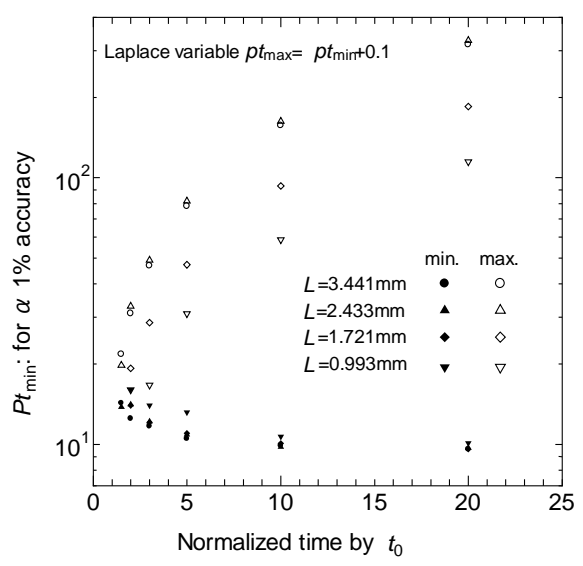

Fig. $4 p t_{\min }$ for obtaining $\alpha$ with an accuracy within $1 \%$

解析に用いるラプラス変数の上限 $p_{\text {max }}$ については時刻 原点付近における測定データと試料温度理論式の差によ り決定され，実空間における最大の測定時間を $t_{\mathrm{m}}$ として $t_{\mathrm{m}}$ が特性時間の 20 倍以上の測定時間の場合, 文献[11]に よる方法 $\left(8 \leq p \times t_{\mathrm{m}} \leq 12\right)$ より大きいラプラス変数が良いと 考えられるが, 解析に使用するデータ測定時間が短くなる ことが想定される場合には, $p \times t_{\mathrm{m}}=14 \sim 16$ 程度に設定す ることが望ましいと考えられる. 文献[11]はラプラス変数 下限 $p_{\text {min }}$ をデータ有限性に基づく誤差抑制の観点から設 定され, ラプラス変数上限 $p_{\max }$ は実験・経験より設定され 
ているが, データ点数 $\left(=t_{\mathrm{m}} / t_{\mathrm{s}}\right) 200$ 点程度での検討であり, 時刻原点誤差に起因する解析誤差を抑制するためラプラ ス変数上限を 12 程度の小さい值に設定されたのではない かと考えられる.これより特性時間当たりのサンプリング データ数が少ないほじ, ラプラス変数上限を小さくするこ とが望ましいと考えられる.

\section{3. 解析結果}

図 3 に示す単層試料裏面温度データを全ての層の密度, 比熱容量, 熱拡散率が同じ值を有する積層試料と想定し, 2 層試料および 3 層試料を想定した直接法, 時定数法の解 析を行い, 解析結果の図 3 で設定した物性值（熱拡散率： $1.0 \mathrm{E}-4 \mathrm{~m}^{2} / \mathrm{s}$, ビオ数 : 0.01) に対する誤差を求めた. 比熱 容量は本解析方法が解析対象でない層の比熱容量に対す る相対的測定となるので解析対象でない層の比熱容量を $1.0 \mathrm{~kJ} / \mathrm{kg} / \mathrm{K}$ としてこの值に対する䛊差を求めた. また直接 法を用いて解析に用いる測定時間を変更して解析精度と の関係を調べた. 解析においては解析対象層以外の層の熱 物性值は既知とした. 試料裏面温度データのラプラス变数 の設定は Eq.(2.22)を用い, 前項結果を元に $p t_{\min }=13$, $p t_{\max }=14, n_{\mathrm{p}}=5$ とした.

\section{12 層試料第 1 層解析}

図 3 のデータを 2 層試料と想定して第 2 層を熱物性值既 知として第 1 層の熱物性值を解析した. 時定数法および直 接法による解析結果を図 5 , 図 6 に示す. 横軸は第 1 層厚 さの全厚さに対する比 $\left(\mathrm{d}_{1} / L\right)$ である.

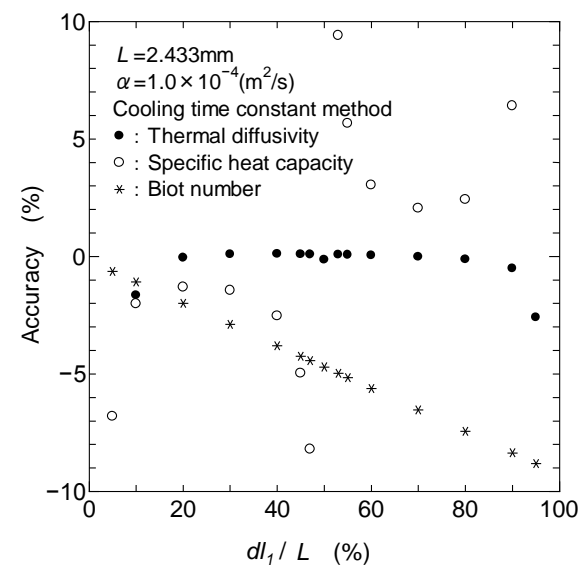

Fig. 5 The accuracy of the thermophysical properties of the $1^{\text {st }}$ layer

(Cooling time constant method)

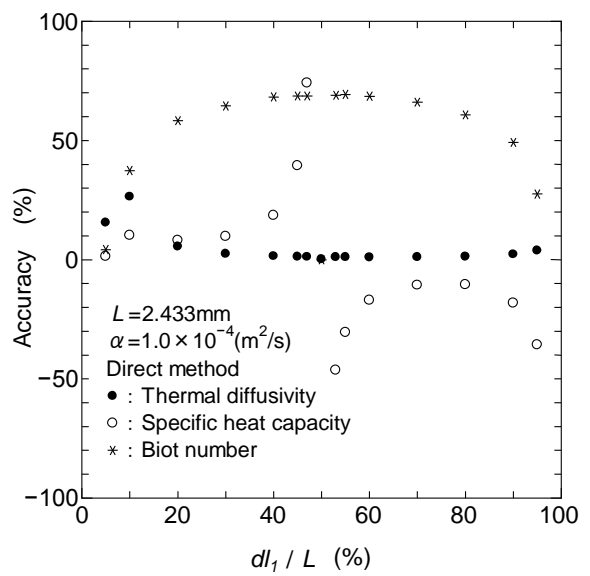

Fig. 6 The accuracy of the thermophysical properties of the $1^{\text {st }}$ layer (Direct method)

熱拡散率解析精度が $5 \%$ より 良い厚さ比は, 時定数法で 10〜95\%, 直接法で 30～95\%付近となった. 熱拡散率, 比熱容量, ビオ数の解析精度は, 時定数法が直接法より高 い. この理由として時定数法の場合, 時定数の測定值と理 論式を等しいとする条件のもとに二乗偏差最小值を探索 するため, 直接法に比較して精度が高くなると考えられる.

図 5 の時定数法による解析で第 1 層厚さが全厚さの 10\%の場合における最小二乗法による解析例を図 7 に示 す. 同図には, ラプラス空間における解析前の試料裹面温 度と解析後の試料裏面温度および解析結果を記載した. 最 小二乗法により求められるデータと実際の測定データを 模擬して計算したデータから得られた值は良く一致して いる.

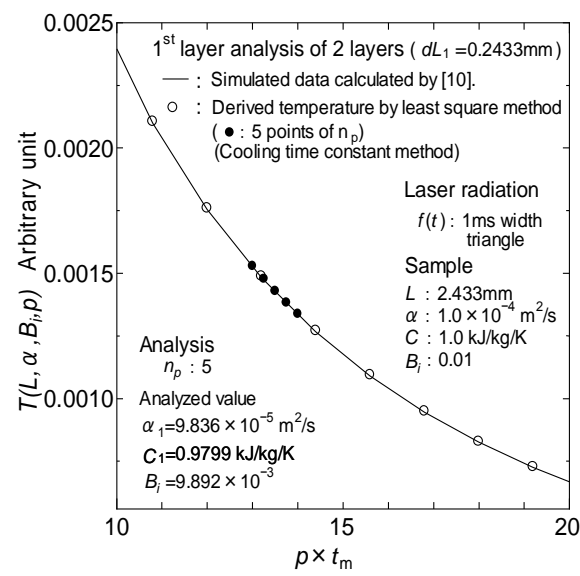

Fig. 7 An example of simulated data (Fig.3) and derived temperature response by the least square method (Cooling time constant method ) 


\section{23 層試料第 2 層解析}

図 3 のデータを 3 層試料と想定して第 2 層の熱物性值解 析を行った. 時定数法および直接法による第 2 層熱物性值 解析結果を図 8 , 困 9 に示す. 横軸は第 2 層厚さの全厚さ に対する比であり，第 1 層と第 3 層厚さは同一とした.

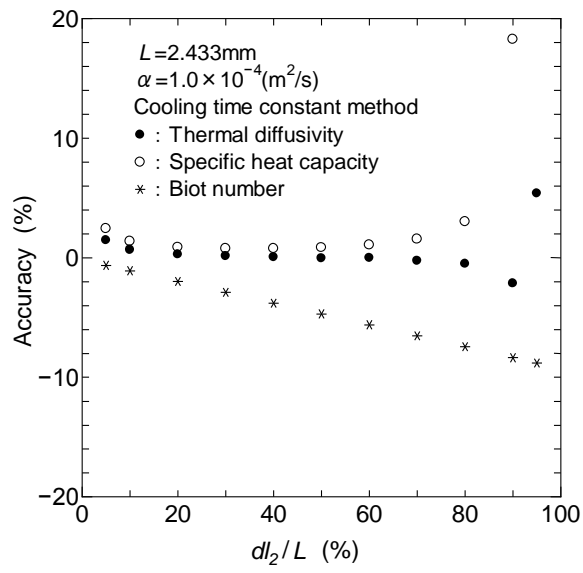

Fig. 8 The accuracy of the thermophysical properties of the $2^{\text {nd }}$ layer

(Cooling time constant method)

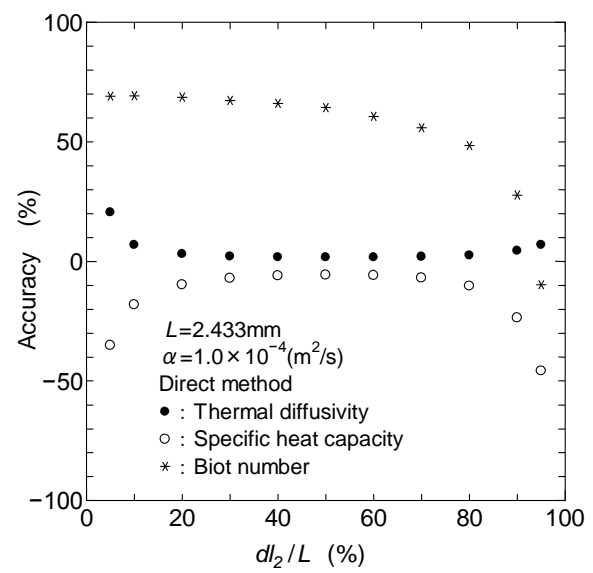

Fig. 9 The accuracy of the thermophysical properties of $2^{\text {nd }}$ layer (Direct method)

熱拡散率解析精度が $5 \%$ より高い厚さ比は時定数法で 5 〜 90\%，直接法で 20～90\% となった. ビオ数解析精度は 時定数法で 1〜 10\%，直接法で 10\%～70\%程度となった. 熱拡散率, 比熱容量, ビオ数の解析精度は, 3(1)項に記載 したように試料の温度低下部から熱放射損失を見積もる ため， 2 層試料同様，時定数法が直接法よりも高い.
3. 3 解析に用いるデータ測定時間と精度

直接法は試料裹面温度データ低下の減衰時定数を使用 しないので解析に用いるデータ測定時間を任意に設定可 能である. 3 層試料第 2 層の熱物性值の解析精度の規格化 時間に対する依存性を求めたものを図 10 に示す．第 2 層 厚さを全厚さの $50 \%$ とし, 表裏面層厚さをそれぞれ全厚 さの $25 \%$ とした．解析に用いるデータ測定時間は特性時 間（ $t_{0}=L^{2} / \pi^{2} / \alpha ）$ を単位とした規格化時間を用いた。

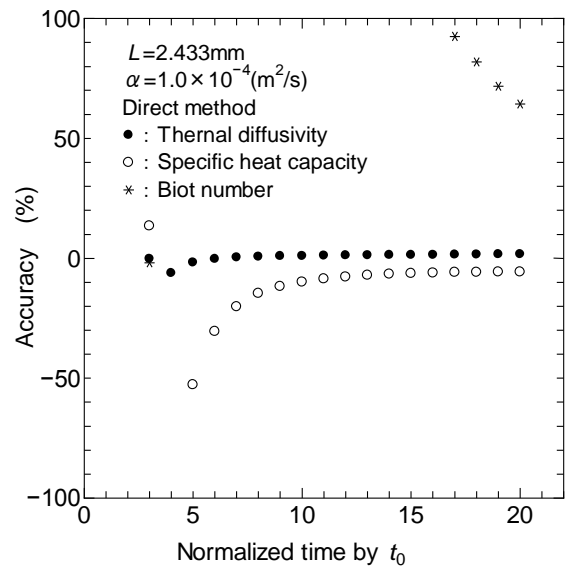

Fig. 10 The accuracy dependence on the data amount of the $2^{\text {nd }}$ layer thermophysical properties

熱拡散率が $5 \%$ より良い精度で得られる規格化時間は 5 以上となった. ビオ数が反映されるデータ測定時間領域は 測定時間後方であり, 測定時間が短くなるに従い，はじめ にビオ数の精度が低下する. 一方, 熱拡散率および比熱容 量特性は加熱直後の裏面温度立ち上がり領域に主に反映 されるため, 比較的短い規格化時間まで精度は低下しない.

3.4 比熱容量の熱拡散率精度への影響

図 3 のデータを同じ密度, 比熱容量, 熱拡散率を有する 3 層試料と想定し，第 1 層および第 3 層厚さを $0.8 \mathrm{~mm}$, 第 2 層厚さ $0.833 \mathrm{~mm}$ として第 2 層熱拡散率解析を行った. この際, 第 2 層比熱容量を解析対象からはずして真值と異 なる值に固定して第 2 層熱拡散率を解析し, この比熱容量 の真值との誤差が第 2 層熱拡散率解析精度に及ぼす影響 について調べた結果を図 11 に示す.

比熱容量を $20 \%$ 程度変化させても熱拡散率の值の変化 は $10 \%$ 弱であり，比熱容量の熱拡散率解析に与える影響 は小さいことが確認された. 


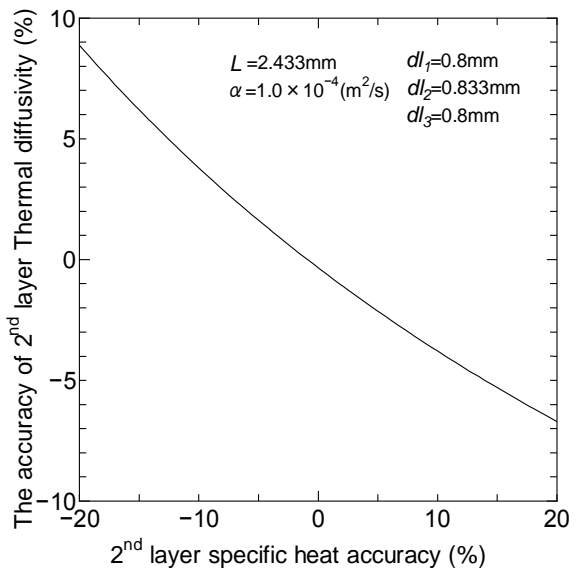

Fig. 11 The relationship between the accuracy of the $2^{\text {nd }}$ layer thermal diffusivity and the accuracy of the $2^{\text {nd }}$ layer specific heat

\section{(Cooling time constant method)}

\section{5 比熱容量の同時解析}

2 層試料第 1 層解析結果は図 5, 図 6 にも見られるよう に $\mathrm{dl}_{1} / \mathrm{L}$ が $50 \%$ 付近に比熱容量解析精度が悪くなる領域が ある.この現象は以下に示すように 2 層材両層の特性時間 $\left(t_{0 \mathrm{i}}=\left(d l_{\mathrm{i}}\right)^{2} / \pi^{2} / \alpha_{\mathrm{i}}\right)$ が近い值を持つ時に生じる. 試料裹面 温度式 Eq.(2.13)において 2 層材で放射損失がない $\left(B_{\mathrm{i} 0}=B_{\mathrm{i}}=0\right)$ ものとすると Eq.(3.1)が得られる.

$$
\bar{T}_{2}\left(L_{2}, p\right)=\frac{Q f(p) 2}{k_{1} r_{1}\left[\begin{array}{l}
\left(1-\frac{k_{2} r_{2}}{k_{1} r_{1}}\right) \frac{\exp \left(+r_{1} d l_{1}-r_{2} d l_{2}\right)}{2} \\
+\left(1+\frac{k_{2} r_{2}}{k_{1} r_{1}}\right) \frac{\exp \left(+r_{1} d l_{1}+r_{2} d l_{2}\right)}{2} \\
-\left(1+\frac{k_{2} r_{2}}{k_{1} r_{1}}\right) \frac{\exp \left(-r_{1} d l_{1}-r_{2} d l_{2}\right)}{2} \\
-\left(1-\frac{k_{2} r_{2}}{k_{1} r_{1}}\right) \frac{\exp \left(-r_{1} d l_{1}+r_{2} d l_{2}\right)}{2}
\end{array}\right]}
$$

上式において各層の特性時間が等しい場合, $r_{1} d l_{1}=r_{2} d l_{2}$ となり裏面温度は Eq.(3.2)となる.

$$
\left.\bar{T}_{2}\left(L_{2}, p\right)=\frac{2 Q}{\left(\rho_{1} C_{1} \sqrt{\alpha_{1}}+\rho_{2} C_{2} \sqrt{\alpha_{2}}\right)}\right) \frac{f(p)}{\sqrt{p} \sinh \left(r_{1} d l_{1}+r_{2} d l_{2}\right)}
$$

\section{この式は 2 層材両層の特性時間が等しい条件が成立する} 時には最高上昇温度で規格化した裏面温度が比熱容量に 依存しないことを表している. 本論文の二乗偏差解析にお
いては, 規格化した裏面温度を用いているので，比熱容量 は求められないことになる。この条件は荒木ら[3]により 試料の比熱容量の影響を受けずに 2 層材の一方の層の熱 拡散率を測定するための条件 $\left(d l_{1} / \sqrt{\alpha_{1}}=d l_{2} / \sqrt{\alpha_{2}}\right)$ とし て発表されている. 本測定でも厳密に上記条件が成立しな い場合でも, 図 4, 図 5 に見られるようにこの条件に近い 場合には比熱容量の解析誤差が大きくなる. 3 層以上の積 層材の表面層あるいは裹面層の比熱容量解析においても, 各層の物性值により同様の現象が生じることが考えられ る. またこの方法は, 解析対象外の層の熱容量に対する対 象層の熱容量の比が小さい領域と大きい領域は解析誤差 が大きい.こうした領域を避けると比熱容量の解析を行う ことができる. 図 3 のデータに対して内部層厚さの全厚さ に対する比が 20〜 70\%程度で約 10\%の精度で解析するこ とができた.

\section{4. 結 論}

レーザフラッシュ法を用いた積層試料の熱拡散率測定 を想定して試料表裹面からの放射損失を考慮した試料裏 面温度式をラプラス空間で導き, 同式を用いて積層試料の 熱拡散率解析を検討し，以下のことが明らかとなった.

1. 積層試料の熱拡散率の解析法として直接法および時 定数法を取り上げ, 両者とも積層試料の熱拡散率およ び放射損失を表すビオ数を解析できることを確認し た. また時定数法のほうが直接法より熱拡散率, ビオ 数の解析精度が高い.

2. 時定数法で使用する理論時定数式およびその近似式 Eq.(2.26)を積層試料に対して導いた. この時定数近似 式の精度は, ビオ数が 0.02 より小さい時 $1 \%$ より高く なることを確認し，その概略の適用条件を求めた。

3. 直接法は時定数を使用しないため, 短いデータ測定時 間で解析可能であり, 熱拡散率は特性時間の 5 倍程度 以上の規格化時間で $5 \%$ の精度向上が見込まれる.

4. 解析対象以外の物性值精度が解析対象層の熱拡散率 精度に影響を及ぼす. 一例として 3 層試料第 2 層の比 熱容量設定誤差の第 2 層熱拡散率解析誤差に及ぼす 影響を確認し, 熱拡散率解析誤差は比熱容量設定誤差 の半分程度となった.

5. 比熱容量同時解析は, 比熱容量が解析不能な条件が存 在する.この条件を避ければ測定を行うことができる. 3 層試料の内部層について解析を行い熱拡散率に比較 して精度が悪いものの解析できることを確認した. 


\section{NOMENCLATURE}

$T_{i .}: i^{\text {th }}$ layer temperature, $\mathrm{K}$

$T_{0 .}$ : steady state temperature, $\mathrm{K}$

$\alpha_{i}: i^{\text {th }}$ layer thermal diffusivity, $\mathrm{m}^{2} / \mathrm{s}$

$C_{i} \quad: i^{\text {th }}$ layer specific heat capacity, $\mathrm{kJ} / \mathrm{kg} / \mathrm{K}$

$\rho_{i}: i^{\text {th }}$ layer density, $\mathrm{g} / \mathrm{m}^{3}$

$k_{i} \quad: i^{\text {th }}$ layer thermal conductivity, $\mathrm{W} / \mathrm{m} / \mathrm{K}$

$n \quad$ : number of layers

$n_{\mathrm{p}} \quad$ : number of laplace variables

$Q f(t)$ : absorbed heat flux from laser, $\mathrm{W} / \mathrm{m}^{2}$

$B_{i 0} \quad$ : Biot number of front surface

$B_{i 1} \quad$ : Biot number of rear surface

$d l_{i} \quad: i^{\text {th }}$ layer thickness, $\mathrm{m}$

$L_{i} \quad$ : thickness $\left(=\sum d l_{j} \quad j=1 \sim i\right), \mathrm{m}$

$x$ : coordinate, $\mathrm{m}$

$t \quad$ : time, $\mathrm{s}$

$t_{0}$ : characteristic time $\left(=L^{2} / \pi^{2} / \alpha\right), \mathrm{s}$

$t_{\mathrm{s}} \quad$ : sampling period, $\mathrm{s}$

$p \quad$ : laplace variable, $1 / \mathrm{s}$

$r_{i}:=\sqrt{p / \alpha_{i}}, 1 / \mathrm{m}$

$\tau_{\text {th }}$ : cooling time constant by theory, $\mathrm{s}$

$\tau_{\mathrm{m}}$ : cooling time constant of data, $\mathrm{s}$

$t_{\mathrm{m}} \quad$ : maximum time of data acquisition, $\mathrm{s}$

$\mathrm{n}_{\mathrm{t}} \quad$ : number for $t_{\mathrm{m}}$ expression by $t_{0}$ unit $\left(=t_{\mathrm{m}} / t_{0}\right)$

$p t_{\min }, p t_{\max }:$ constant for laplace variable setting

$p_{\min ,}, p_{\max }$ : minimum and maximum of laplace variable (1/s)

$\sigma \quad$ : Stefan-Boltzmann constant, $\mathrm{W} / \mathrm{m}^{2} / \mathrm{K}^{4}$

$\varepsilon \quad$ : emissivity

\section{参考文献}

[1] T.Baba; $\lceil$ Analysis of One-dimensional Heat Diffusion after Light Pulse Heating by the Response Function Method」, Jpn.J.Appl.Phys. 48 (2009) 05EB04.

[2] M.Akoshima, T.Tanaka, S.Endo, T.Baba, Y.Harada, Y.Kojima, A.Kawasaki, F.Ono; 「Thermal Diffusivity Measurement for Thermal Spray Coating Attached to Substrate Using Laser Flash Method」, Jpn. J. Appl. Phys. 50 (2011) 11RE01.

[3] 荒木信幸，牧野敦，三原純;「レーザフラッシュ法に よる層状試料の熱拡散率測定における問題点」第 9 回 熱物性シンポジウム講演論文集 (1988) 179-182.

[4] 早稲田嘉夫, 太田弘道, 柴田浩幸, 渡辺啓二, 中 島敬治; 「有限要素法によるレーザフラッシュ示差 3 層試料法を用いた液体の熱拡散率測定における熱損失 の検討」, 高温学会誌 20 (1994) 104-112.

[5] K.B.Larson, K.Koyama; 「Measurement by the Flash Method of Thermal Diffusivity, Heat Capacity, and Thermal Conductivity in Two-Layer Composite
Samples」, J. Appl. Phys. Phys. 39 (1968) 4408-4416.

[6] 細野和也, 堂園利憲; 「レーザフラッシュ法による熱 伝導率解析法」, 第 16 回熱物性シンポジウム講演論 文集 (1995) 373-376.

[7] 細野和也; 「レーザフラッシュ法による黒化膜の熱拡 散率測定」, 第 28 回熱物性シンポジウム講演論文集 (2007) 211-213.

[8] 高橋洋一, 安積忠彦, 菅野昌義：「レーザフラッシュ 法熱拡散率測定法の改良 ( I )」, 熱測定, 8 (1981) 62-66.

[9] 太田弘道, 早稲田嘉夫; 「レーザフラッシュ法による ボロンナイトライド及びサファイアの熱拡散率測定」, 窯業協会誌, 94 (1986) 295-299.

[10] J.A.Cape, G.W.Lehman; 「Temperature and Finite Pulse-Time Effects in the Flash Method for Measuring Thermal Diffusivity」, J.App.Phys. 34 (1963) 1909-1913.

[11］飯田嘉宏，重田治彦；「任意加熱による熱物性值の 測定法に関する研究」, 日本機械学会論文集 (1981) 470-477.

[Received Oct .3, 2017, Accepted Jan.18, 2018] 